UDC: $331.446 .4: 622$

DOI: https://doi.org/10.24195/2414-4665-2019-3-1

Inessa Viznyuk,

PhD (Candidate of Psychological Sciences), associate professor, Department of Psychology and Social Work,

Vinnitsa State Pedagogical Mikhail Kotsyubynsky University, 32, Ostrozky Str., Vinnitsa, Ukraine

\title{
PEDAGOGICAL SKILLS OF THE TEACHER AS A MEANS OF FORMING A HEALTHY LIFESTYLE AMONG STUDENTS
}

The article considers the phenomenon of teacher's personal maturity as a key factor in the effectiveness of pedagogical activity. The purpose of our article is to substantiate the pedagogical skills of the teacher as a means of forming a healthy life. Generalization of various approaches gives the grounds to allocate some bipolar parameters which have great value in a context of pedagogical activity and characterize the level of a personal maturity or, accordingly, immaturity of the teacher. Based on the analysis of psychological and pedagogical approaches to the interpretation of the essence of personal development, we determine the following criteria of the teacher's personal maturity: self-determination, capacity for self-awareness, spontaneity, authenticity, readiness for emotionally close relationships, etc., as well as the adequacy of self-perception, flexibility, tolerance for contradictions, understanding of the relativity of things, positive self-image, inclination for creativity, existence of individual life philosophy and professional position. The humanization of the school and the organization of the educational process on the basis of a personal approach requires the teacher to have a high level of personal maturity, who can present him/herself to the students not as an impersonal functionary, professional, but as an original personality, who has his/her own position, which is open in expression, their feelings, emotions and views. Teaching such teachers requires the realization of a set of pedagogical conditions in the educational environment of higher education institutions, connected with ensuring the subjective position of students, intensifying their reflective processes, dialogue, problematization and personalization of pedagogical communication. The preparation of such teachers requires the realization in the educational space of a higher educational institution of a complex of pedagogical conditions connected with the maintenance of the subject position of students, activation of their reflexive processes, dialogical character, personification and complication of pedagogical interaction, Psychology of Technology and Social Psychology.

Keywords: maturity, personal maturity, criteria of teacher's personal maturity, development of teacher's personal maturity.

\section{Introduction}

The personality of the teacher was always considered as a decisive factor in the efficiency of upbringing. The outstanding teachers of the past constantly stressed that the success of upbringing depends not only on the subject competence and a teacher's skill in teaching methods but above all on his/her personal qualities. This dependence becomes even more evident in terms of changing the education system to the personal approach in the context of which the stress is put on the development of the personal characteristics of students: subjectivity, autonomy, reflexivity, createvity, inner freedom, responsibility and so on. The methodology of the personal approach requires a transition to such a style of educational relationships that ensures the formation of subjectiveness as the pupils' ability to consciously, creatively and independently to determine their own life, to take responsibilities for their actions. The personal development of students, in its turn, is possible only on condition that there is the appropriate level of personal ripeness of the teacher: "for the child's correct personal development, it is necessary that first of all, the teachers themselves possess the adequate personal organization".

It is difficult to imagine, how the teacher can promote harmonization of the personality of students if he/she him/herself is not deprived of psychological complexes and internal contradictions. In R. Burns' opinion, teachers with the negative self-concept "experience social and emotional difficulties which cause uneasiness, generate stress and finally should for sure be reflected in their teaching work" (Osukhova, 1991). N. Osukhova fairly notices that "by means of intimidated and conformed teacher who does not accept him/herself and others, it is impossible to solve a problem of a school humanization". Psychological and pedagogical researches testify that "together with cognitive development of the teacher the important requirement, which is necessary to consider in the course of vocational training, is his/her general psychological tone and adequacy of personal regulation" (Berns, 1986). Whatever pedagogical techniques, methods and modes the teacher did not own; he/she should show the students, first of all, the sample of the psychological health and personal maturity.

Numerous researches testify the importance of personality maturity of the teacher as preconditions of efficiency of pedagogical activity and in these researches the existence of indissoluble connection between personal characteristics of the tutor and personal formation of students is proved (R. Burns, U. Glasser, I. Dubrovina, A. Markova, L. Mitina, A. Orlov, C. Rogers and others). The personal maturity of the teacher defines a humanistic orientation of his/her actions and deeds, ability to creative self-realization and self-development in professional work space. Therefore, in the course of vocational training of the future teachers, the character and an orientation of personal development of students has not smaller importance, than 
the academic achievements. In this connection, the development of a personal maturity of the future teachers should become one of priority tasks of their vocational training.

A. Maslow considers the personal development of man in connection with the concept of self-actualization, which means the fullest disclosure of the inherent innate potencies (Maslou, 1999). He pointed to the characteristics that distinguish self-actualized personalities: the highest degree of perception of reality; the developed ability to perceive yourself, others and the world at large as they really are; the increased spontaneity; the developed ability to focus on a problem; a more expressed desire for solitude; autonomy, opposition to any involvement of another culture; perception of freshness and richness of emotional reactions; frequent breaks in peak experiences; identifying itself with the whole human race; capacity for constructive interpersonal relationships; democratic structure of one's character; developed creative abilities.

To describe the phenomenon of personal maturity C. Rogers used the term "fully functioning person". The main characteristics of a fully functioning are the following: openness to experience, lack of fear of your own feelings, whatever they may be - negative or positive; living in the present with full awareness of each moment, being ready to rebuild their own behavior to the extent that the experience provides new opportunities, flexibility and ability to adapt to changing conditions of life; self-belief, your inner motivation and intuition, ever-growing confidence in their own ability to make decisions (Rogers,1994).

It should be emphasized that according to most scholars between the chronological age and personal maturity of the individual there is no direct dependence. Responding intellectually and socially to his/her age, the individual may be characterized by a low level of personal maturity (S. Kovi, G. Allport, E. Fromm, P. Hersey and others)

\section{Aim and Tasks}

The purpose of our article is to substantiate the pedagogical skills of the teacher as a means of forming a healthy life.

\section{Research Methods}

The majority of researchers, considering a phenomenon of a personal maturity, focuses attention on such characteristics of the person, as self-determination, self-control in a counterbalance of external determination; creativity in a counterbalance to reproduction; individuality, authenticity in a counterbalance to standardization, banality; initiative in a counterbalance to passivity; self-esteem in a counterbalance to a negative self-estimation; a personal openness in a counterbalance to an estrangement and closeness; reflexivity in a counterbalance to an impulsiveness; flexibility, understanding of a relativity of things in a counterbalance to rigidness, compartmentalization; realness of perception of the reality in a counterbalance to stereotype and bias. It is obvious that the personal maturity has not one-dimensional, but multidimensional structure, i.e. it integrates the complex of interconnected traits. Generalization of various approaches gives the grounds to allocate some bipolar parameters which have great value in a context of pedagogical activity and characterize the level of a personal maturity or, accordingly, immaturity of the teacher.

Proactivity (self-determination, autonomy, initiativeness) - activity (passiveness, dependence, orientation to authorities). One of the main features is the maturity of the individual autonomy, inner freedom - the ability to distance him/herself from both impact of the environment and the principles on which behavior has been based up to the present moment. A mature person is able to switch from one to the other activity determinants, to choose between alternatives, to resist the temptations and distractive factors, to change arbitrarily leading principles of behavior (Kon, 1989). The self-determination ability becomes particularly important in the context of the personality-oriented approach, which requires the teacher to show willingness over situational activity, to resist generally-accepted patterns and pedagogical routine, defend own creative freedom and uniqueness, critical treatment of widelyknown facts.

Reflexivity, a reflexive ability to go beyond the accomplished activities - activity absorption, inability to go beyond its boundaries and look at him/herself and own actions from the perspective of an observer. The most important feature of reflection is that it allows the individual to go beyond the accomplished activities and look at $\mathrm{him} /$ herself as if from another side, from the position "over" and "behind" to control his/her own activity based on awareness of him/herself and own actions. A person becomes an object of control by him/herself through reflection. Reflection allows the teacher to be a full author that constructs his/her present day and future, allows to understand and evaluate the difficulties and contradictions of educational process, resolve them independently and constructively according to his/her own orientations on values, to consider the problem as a stimulus for further development, overcoming own limitations. The teacher's awareness of his/her own potential, prospects for personal and professional growth prompts him/her to constant experimentation, creativity. Hence reflection can be seen as an important means of professional self-development, a condition and factor of the personal development. Self-observations and analysis of the own actions in different situations as if through the eyes of another person help the teacher to understand the peculiarities of professional and role behavior and thus allows to correct it. Only thanks to reflection the teacher becomes a real participant in the sense that he or she can consciously and deliberately transform him/herself, to question and change those principles, which are based on his/her actions.

Spontaneity, authenticity, no fear of self-disclosure, the ability to emotionally close relationships - being closed, hiding behind various social masks and facades, fear of emotionally close relationships. C. Rogers states that the personal development of pupils is determined by the ability of the teacher to form when communicating with them a special type of interpersonal relationships that he calls "helping ones". One of the conditions of such relationships is the congruence of experiences and behavior of the teacher (Rogers, 1994). This means a sincere, frank, direct and conscious manifestation of teacher's own feelings, his/her attitudes towards his/her pupils. "The facial", alienated, formal communication is the opposition to the congruent, when the teacher hides his/her true feelings under a role professionally impersonal mask. A. Orlov notes: "If a teacher's behavior is insincere, he/she tends to hide behind the guise of various kinds ("facades", "stripes") if he/she 
shows negligence or cold senseless ... he/she adversely affects his/her pupils' personal development" (Orlov, 2002). The reason for the teacher's avoiding close, open relationships with his/her pupils may be his/her low level of personal maturity, manifested in anxiety, deep concern, doubt about the ability to cause the sympathy and respect. The spontaneous teachers build their communication with pupils on the basis of personal feelings, rather than social-role expectations, openly show their qualities and emotions, come to the students individually, paying attention not only and not so much to their competencies and academic achievements, but to the personal traits, extracurricular interests and inclinations.

The realistic perception of themselves and the environment, the ability to see things and other people as they really are - is a distorted perception of reality due to the impact of different kinds of unconscious attitudes, stereotypes and psychological defense mechanisms. Personally mature teachers are distinguished by a more adequate perception of reality; know themselves better and easier perceive themselves as they are. They are characterized by a less dependence on the mechanisms of psychological defense; in particular, they are not characterized by the distorted perception of themselves and the pupils, which often reduces the teachers' activity with a less psychological harmonious type. Often teachers with low level of personal maturity perceive themselves limited - only as performers of respective social role. This makes the teacher's activity poorer, dehumanizes his/her activity, because the personality is always broader and richer than any role. For example, it is important for teachers not only teach but also learn, that is to go beyond their role. Taking into mind only what corresponds to the social role, and discarding the rest, the teacher limits his/her personality, turning it into a kind of mask, behind which it is impossible to make out a living person. Another, also negative consequence of inadequate self-image Psychology explains the known pattern: the more difficult for a person to perceive oneself, the more difficult it to take the others. The teacher is not able to perceive pupils as they are, denying their right to be themselves, which causes communication barriers of psychological conflicts and brings to nothing the educational effort (Bozhovych, 2001).

The internal locus of control, taking responsibility for their actions themselves is the external locus of control, attribution of responsibility to the environment. The results of the research indicate that teachers with an internal locus of control tend to take responsibility for the consequences of their actions, have a higher level of personal maturity than the teachers with an external locus of control that shift responsibility to others: colleagues, pupils or their parents. Teachers from the internal locus of control are characterized by kindness, tolerance, altruism, perseverance, selfcriticism, a tendency to critically analyze their own actions.

Tolerance, flexibility, tolerance of contradictions, dissimilarities, understanding of the relativity of things, openness to everything new - intolerance, being categorical, dichotomous ("black-and-white") thinking, rejection of alternative views. The personal development of pupils depends on the teachers' ability to accept different points of view tolerantly, to recognize children's rights to their own position. Tolerance is the result of the teacher's conscious choice of this position in the relationships with the pupils, resulting from the understanding, acceptance and respect for plurality and diversity of life, recognizing the inevitability of individual differences, and - preparedness to build their own world so strong and flexible, to be open to interaction with the others. The teacher should have sufficient intellectual flexibility, not to be dogmatic, not state that there is only one way to solve the problem, the one and only correct view. Unfortunately, in daily teaching practice frequently observed manifestations of the teachers' intolerance - from indifference to the child's own opinion to frank and hard impaired and even the humiliation of the pupil for the "wrong views". This behavior shows primarily the low level of personal maturity teacher.

A positive self-concept, self-confidence - a negative self-concept, self-diffidence. R. Burns's research shows that authoritarian tendencies in communication are often inherent to diffident teachers with negative self-esteem, who possess personal inadequacy, anxiety and insecurity, and who are identified with authoritarian roles which are manifested both with the excessive cruelty and authoritativeness and as well as the desire to appear confident in his/her students' eyes. And vice versa, a teacher with a positive self-esteem, "feeling confident in the classroom, does not feel obliged to psychologically defend himself/herself ... easily accepts the fact of being limited in his/her opportunities and capabilities of students ... will be friendly and at the same time turn to justify criticism on occasion" (Burns, 1986). Self-confidence helps the teacher to overcome fear and anxiety, to enjoy the progress and not to despair, facing difficulties to remain emotionally balanced and flexible enough to interact with students for a long time (Morhun \& Tkacheva, 1996).

Creativity, enthusiasm, inclination for risk, the creative transformation of reality - a reproductive orientation, stereotyping, fear of risk, a tendency of keeping to established standards. Practice shows that those teachers who have an expressed belief, passionate about something (their subject, ideas) deeply and truly believe in something (truth, beauty, goodness, justice, freedom and self-worth of each person) help to the personal development of students. Typically, children recognize easily the spiritual emptiness, distrust and false in teacher's actions and internally try to suspend from him/her. Only those teachers who are characterized by bright personality and creativity can be not just sources and transmitters of information, not just good people, but also to be the catalyst for personal growth of students (Leontev, 2011).

The presence of the own life Philosophy and personal and professional position - an amorphous idea about their life and professional priorities, passive perception of externally imposed values and principles. Unlike those who passively and uncritically accept the goals and values which are imposed by the environment, mature teachers have a clear idea of what their lives, professional aspirations and beliefs should be like. They must be aware of what they want, plan their lives and organize their professional activities accordingly. They are characterized by a sense of confidence, stability and optimism for the future. Temporary life and professional difficulties do not reduce their desire to follow the chosen strategy. His/her goals,values and beliefs as they experience personally meaningful, such as providing a sense of directional and 
meaningfulness of life, professional activities (Sukhobskaia, 2002).

The analysis of domestic and foreign Psychology and pedagogical concepts of the personally-focused educational interaction gives the grounds to allocate some pedagogical conditions necessary for stimulation of subject activity and, accordingly, of development of a personal maturity of pedagogical high schools students. The first of them consists in transition from monologue to dialogical strategy of pedagogical interaction. At monologue strategy the teacher operates thus as if only he/she is the full subject and the carrier of the truth. Unlike it, dialogical strategy is based on a recognition of subjective full value and basic equality of co-operating partners and in this sense abstracts from possible differences in the social status of the teacher and students.

\section{Research Results}

Researchers consider as base characteristics of dialogical pedagogical interaction: mutual trust, an openness, goodwill, the common vision of situations by the teacher and students, a mutual orientation on the problems solving, equality of psychological positions, mutual understanding (L. Petrovskaya, A. Spivakovskaya); equality, mutual trust, mutual understanding, mutual sympathy (R. Karneev); orientation to equality in communication, aspiration to mutual understanding, co-creation and mutual development (S. Bratchenko); personal orientation, equality of psychological positions, mutual penetration into the world of feelings and experiences, readiness to accept the partner's point of view, a withdrawal from especially role position (N. Ostroverhova). Despite certain differences, the majority of researchers recognize the most effective from the stand point of creating favorable conditions for their personal development in terms of teaching pedagogy, subjects the dialogical, the subject-subject strategy of interaction which presupposes_perception of students as partners psychologically equal in rights; certainly positive relation to them and belief in their potential creative possibilities; a personal openness and trust; disposing to mutual understanding and creative cooperation; granting to students of a freedom in choosing, the right to personal-professional self-determination.

In process of training work with the future teachers the basic concepts of the human-centered psychotherapeutic approach are made operative (Rogers, 1994), concerning a pedagogical context. The basic postulate, on which such training is based, consists in that quality of pedagogical process is defined by quality of interpersonal dialogue of the teacher and students which, in turn, depends on level of a personal maturity of the teacher, its relation to himself/herself. Hence, the primary goal of training - to promote development and harmonization of the teacher's person, and, thanks to it, to increase the efficiency of pedagogical process as a whole.

\section{REFERENCES}

1. Berns, R. (1986). Razvitie Ya-kontseptsii $i$ vospitanie. [Self-concept development and education]. Moscow: Progress [in Russian].

2. Bozhovych, L. (2001). Problemy formirovaniia lichnosti [Problems of personality formation]. MoscowVoronezh: Moskovskiy psykhologo-sotsyalnyi instytut, MODEK [in Russian].

\section{Discussion}

Group training can be an effective mean of pedagogical support of personal and professional formation of the future teachers, expansion of their personal experience, correction of professional settings, positions, professional identity. Specially organized interpersonal interaction in groups of socially-psychological training gives the chance to students to feel themselves psychologically more protected, self-assured, capable to cooperation, raises their readiness to accept themselves and pupils. All of it considerably facilitates to the future teachers the decision of uneasy problems of dialogue with schoolchildren, does less intense collision with realities of school life. Participation in group training also promotes to correction of inadequate professional stereotypes, formation of students' ability to more objective, unbiased and deep understanding of themselves and surrounding people. Typical effects of sociallypsychological training of the future teachers are: a tendency to give to relations with pupils as much attention and value, as to the subject maintenance; the aspiration to accept innovative, creative ideas of pupils instead of to react to them as on threat to own authority; propensity to resolve interpersonal problems together with pupils, instead of traditional disciplinary means; the general harmonization of the person. Training approaches pedagogical dialogue to therapeutic one, promote personal growth of the future teachers, harmonizing system of their intrapersonal relations.

\section{Conclusions}

Thus, a major factor of education which finally defines its efficiency, the person of the teacher is. As by means of a curve ruler it is impossible to spend a straight line, so by means of immature, intimidated and conformed teacher who does not accept himself/herself and pupils, it is impossible to bring up the mature person. For a school humanization and the organization of pedagogical process on dialogue principles the teacher is necessary, who is characterized by high level of a personal maturity and can appear before pupils not as the faceless functionary, the executor of a professional role, but as the original person having own position, opened in expression of the feelings, emotions and relations. Preparation of such teachers demands realization in educational space of a higher educational institution of a complex of the pedagogical conditions connected with maintenance of a subject position of students, activation of their reflective processes, dialogical character, personification and making problematic of pedagogical interaction, application of technologies of sociallypsychological training of a personal maturity.

3. Kon, I. (1989). Psykholokhiia rannei yunosti [The Psychology of Early Youth]. Moscow: Prosvishchenie [in Russian].

4. Leontev, D. (2011). Lychnostnyi potentsyal: struktura y dyahnostyka [Personal potential: structure and diagnosis]. Moscow: Smysl [in Russian].

5. Maslow, A. (1999). Motyvatsyia y lychnost [Motivation and personality]. (A. M. Tatlobaevoi, Trans.). 
Evraziia [in Russian].

6. Morhun, V. \& Tkacheva, N. (1996). Problema periodizatsii razitiia lichnosti $v$ psikhologii [The problem of periodization of personality development in Psychology]. Voronezh: NPO «MODEK» [in Russian].

7. Olport, H. (2002). Stanovlenie lichnosti: izbrannye trudy [Becoming Personality: Selected Works], Moscow: Smysl [in Russian].

8. Orlov, A. (2002). Psykholohiia lichnosti $i$ sushchnosti cheloveka: Paradigmy, proektsii, praktiki [Psychology of the personality and essence of man: Paradigms, projections, practices]. Moscow: Izdatelskiy tsentr «Akademiia» [in Russian].

9. Osukhova, N. (1991). Humanisticheskie orientatsii uchitelia: peresmotr tseley i poisk tekhnologii [Teacher's Humanistic Orientations: Revising Goals and Finding Technology]. ()VVSh [in Ukrainian].

10. Rodzhers, K. (1994).Vzghliad na psykhoterapiiu. Stanovlenie cheloveka [Looking at psychotherapy. The formation of man]. Moscow: Progress [in Russian].

11. Sukhobskaia, H. (2002). Poniatie «zrelost sotsialno-psykhologicheskogo razvitiia cheloveka» $\mathrm{v}$ kontekste andragogiki [The concept of "maturity of the socio-psychological development of man" in the context of andragogy]. Novye znaniia - New knowlenge, 4, pp. 17-20 [in Russian].

\section{ЛIТЕРАТУРА}

1. Бернс Р. Развитие Я-концепции и воспитание : пер. с англ. Москва : Progress, 1986. 421 с.

2. Божович Л. Проблемы формирования личности. Воронеж : Московский психолого-социальный институт, МОДЭК, 2001. 352 с.

3. Кон І. Психология ранней юности. Москва : Просвещение, 1989. 255 с.

4. Леонтьев Д. Личностный потенциал: структура и диагностика. Москва : Смысл, 2011. 675 с.

5. Маслоу А. Мотивация и личность / Пер. А. М. Татлыбаевой. Евразия, 1999. 478 с.

6. Моргун В., Ткачева Н. Проблема периодизации развития личности в психологии // Изд-во «Институт практической психологии». Воронеж : НПО «МОДЭК», 1996. 512 с.

7. Олпорт Г. Становление личности: избранные труды. Москва : Смысл, 2002. С. 167-169.

8. Орлов А. Психология личности и сущности человека: парадигмы, проекции, практики: учеб. пособие для студ. психол. фак. Вузов. Москва : Издательский центр «Академия», 2002. 272 с.

9. Осухова Н. Гуманистические ориентации учителя: пересмотр целей и поиск технологии. ВВШ, 1991. № 12 . С. $30-36$.

10. Роджерс К. Взгляд на психотерапию. Становление человека. Москва : Прогресс, 1994. 480 с.

11. Сухобская Г. Понятие «зрелость социальнопсихологического развития человека» в контексте андрагогики. Новые знания. 2002. № 4. С. 17-20

Інесса Візнюк,

кандидат психологічних наук, доцент, Вінницький державний педагогічний університет імені Михайла Кочюбинського, вул. Острозького, 32, м. Вінниця, Украӥна

\section{ПЕДАГОГІЧНА МАЙСТЕРНІСТЬ ВЧИТЕЛЯ ЯК ЗАСІБ ФОРМУВАННЯ ЗДОРОВОГО СПОСОБУ ЖИТТЯ}

У статті наведено розгляд явища особистої зрілості вчителя як ключового чинника ефективності педагогічної діяльності. На основі аналізу психолого-педагогічних підходів до інтерпретації сутності особистісного розвитку ми визначаємо такі критерії особистої зрілості вчителя: самовизначення, здатність до самосвідомості, спонтанність, справжність, готовність до емоційно близьких стосунків тощо, а також адекватність самосприйняття та сприйняття оточення, внутрішній контроль, толерантність, гнучкість, толерантне ставлення до суперечностей, розуміння відносності речей, позитивного самоіміджу, схильності до творчості, існування індивідуальної життєвої філософії та професійної позиції. Гуманізація школи та організація навчально-виховного процесу на засадах особистісного підходу вимагає від вчителя високого рівня особистої зрілості, який може представити себе учням не як безособовий функціонер, виконавець професійних обов'язків, а як оригінальна особистість, яка має власну позицію, яка відкрита у вираженні своїх почуттів, емоцій та поглядів. Навчання таких викладачів вимагає реалізації комплексу педагогічних умов у освітньому середовищі вищих навчальних закладів, пов'язаних із забезпеченням суб'єктивної позиції студентів, активізацією їх рефлексивних процесів, діалогізацією, проблематизацією та персоналізацією педагогічного спілкування. Підготовка таких викладачів вимагає реалізації у навчальному просторі вищого навчального закладу комплексу педагогічних умов, пов'язаних із підтримкою предметної позиції студентів, активізацією їх рефлексивних процесів, діалогічного характеру, уособленням та ускладненням педагогічної взаємодії, застосування технології соціально-психологічної підготовки особистісної зрілості.

Ключові слова: зрілість, особистісна зрілість, критерії особистої зрілості вчителя, розвиток особистої зрілості вчителів.

Подано до редакиії 20.08.2019 